grants from: Abbvie, Amgen, Aurora, Bristol-Meyers Squibb, Celgene, Hospira, Janssen, Lilly, Medexus, Merck, Novartis, Pfizer, Roche, Sanofi, \& UCB. Dr. Bombardier held a Canada Research Chair in Knowledge Transfer for Musculoskeletal Care and a Pfizer Research Chair in Rheumatology DOI: 10.1136/annrheumdis-2021-eular.912

\section{OP0180 \\ IMPACT OF RF AND ANTI-CITRULLINATED PROTEIN ANTIBODY SEROSTATUS ON 2-YEAR RETENTION OF ABATACEPT IN PATIENTS WITH RA}

$\underline{\text { R. Alten }}{ }^{1}$, X. Mariette ${ }^{2}$, R. M. Flipo ${ }^{3}$, R. Caporali ${ }^{4,5}$, M. H. Buch ${ }^{6,7}$, Y. Patel $^{8}$, R. Sanmartí ${ }^{9}$, S. Marsal ${ }^{10}$, M. T. Nurmohamed ${ }^{11}$, H. Griffiths $^{12}$, P. Peichl $^{13}$, B. Bannert ${ }^{14}$, A. Forster ${ }^{15}$, M. Chartier ${ }^{16}$, S. Connolly ${ }^{17}$, Y. Elbez ${ }^{18}$, C. Rauch ${ }^{19}$, V. Khaychuk ${ }^{20}$, K. Lozenski ${ }^{21}$. ${ }^{1}$ Schlosspark-Klinik University, Department of Internal Medicine, Rheumatology, Berlin, Germany; ${ }^{2}$ Université Paris-Saclay, AP-HP, Hospital Bicêtre, Department of Rheumatology, Paris, France; ${ }^{3}$ Centre Hospitalier Universitaire de France, Department of Rheumatology, Lille, France; ${ }^{4}$ University of Milan, Department of Clinical Sciences and Community Health, Milan, Italy; ${ }^{5} \mathrm{G}$. Pini Hospital, Clinical Rheumatology Unit, Milan, Italy; ${ }^{6}$ University of Leeds, Leeds Institute for Rheumatic and Musculoskeletal Medicine, Leeds, United Kingdom; ${ }^{7}$ University of Manchester, Division of Musculoskeletal \& Dermatological Sciences, Manchester, United Kingdom; ${ }^{8}$ Hull Royal Infirmary, Rheumatology, Hull, United Kingdom; ${ }^{9}$ Hospital Clinic de Barcelona, Rheumatology Department, Barcelona, Spain; ${ }^{10}$ Hospital Universitari Vall d'Hebron, Rheumatology, Barcelona, Spain; ${ }^{11}$ ARC Amsterdam University Hospitals - VU University Medical \& Reade, Department of Rheumatology, Amsterdam, Netherlands; ${ }^{12}$ University Hospital Geelong, Barwon Rheumatology Service, Geelong, Australia; ${ }^{13}$ Evangelical Hospital, Department of Internal Medicine, Vienna, Austria; ${ }^{14}$ Universitätsspital Basel, Rheumatologische Universitätsklinik, Basel, Switzerland; ${ }^{15}$ Schulthess Klinik, Department of Rheumatology, Zürich, Switzerland; ${ }^{16}$ Bristol Myers Squibb, Non-Registrational Data Generation, Rueil-Malmaison, France; ${ }^{17}$ Bristol Myers Squibb, Global Drug Development, Princeton, United States of America; ${ }^{18}$ Deepscover, Biostatistics, Puteaux, France; ${ }^{19}$ Bristol Myers Squibb, Medical Immunology \& Fibrosis, Munich, Germany; ${ }^{20}$ Bristol Myers Squibb, US Medical Immunology and Fibrosis, Princeton, United States of America; ${ }^{21}$ Bristol Myers Squibb, Immunology and Fibrosis, Princeton, United States of America

Background: Up to $50 \%$ of patients with RA discontinue DMARD treatment within 18 months. ${ }^{1}$ However, up to $20 \%$ of patients who fail multiple treatments may have a good treatment response to another therapy. ${ }^{1}$ Predictive biomarkers, such as RF and anti-citrullinated protein antibodies (ACPAs), may be useful to stratify patients with RA to the most appropriate treatment. ${ }^{1}$ ASCORE (Abatacept SubCutaneOus in Routine Clinical PracticE; NCT02090556) was a 2-year, observational, prospective, multicentre study of SC abatacept for the treatment of RA in routine clinical practice. ${ }^{2}$ Objectives: To determine if RF/ACPA serostatus and treatment line impact abatacept retention in patients with RA in a post hoc analysis of ASCORE.

Methods: Eligible patients, aged $\geq 18$ years, with active moderate-to-severe RA (ACR/EULAR 2010 criteria) who were IV abatacept-naive and initiated SC abatacept $125 \mathrm{mg}$ once weekly, were enrolled into two cohorts: biologic (b) DMARD-naive patients and those with $\geq 1$ prior bDMARD treatment failure. This post hoc analysis assessed abatacept retention rate at 2 years in a subset of patients with RF/ACPA serostatus data $(n=1748)$ from the ASCORE study ( $N=2892$; as observed). Baseline $(B L)$ serostatus groups examined by treatment line were: RF/ACPA double positive $(+/+)$ RA, RF/ACPA single positive (RF+/ACPA- or RF-/ACPA+) RA (data not shown) and RF/ACPA double negative (-/-) RA. Last observation carried forward (LOCF) analyses were used to assess change from $B L$ and measures of disease remission (DAS28 $[C R P]<2.6, C D A I \leq 2.8$, and $S D A I \leq 3.3$ ) in patients with +/+ RA versus -/ $-R A$. Results: BL demographic and disease characteristics were similar across serostatus groups and treatment lines (Table 1). Mean age was 57.1 and 57.8 years for +/+ RA and -/- RA, respectively. Mean DAS28 (CRP) was 4.7 and 4.8 for +/+ RA and -/- RA, respectively. In patients with +/+ RA, abatacept retention was greater when given as first-line treatment $(57 \%$ vs $48 \%$ when given as $\geq$ second-line) (Figure 1). Retention was similar in patients with -/-RA regardless of treatment line. After 2 years, mean (SE) change from BL (LOCF) in DAS28 (CRP) was $-1.41(0.06)$ and -0.97 (0.09) for patients with +/+ and -/- RA, respectively. For patients with $+/+\mathrm{RA}$, mean (SE) change from BL in DAS28 (CRP) was -1.62 $(0.08)$ for those in whom abatacept was first-line and $-1.19(0.08)$ for those in

Table 1. BL demographics and disease characteristics by RF/ACPA status

\begin{tabular}{lcccc}
\hline & \multicolumn{2}{c}{$\begin{array}{c}+/+\mathrm{RA} \\
(\mathbf{n}=\mathbf{1 0 7 9})\end{array}$} & \multicolumn{2}{c}{$\begin{array}{c}\text { l- RA } \\
(\mathbf{n}=\mathbf{3 4 3})\end{array}$} \\
\cline { 2 - 5 } & $\begin{array}{c}\text { First-line } \\
(\mathbf{n}=511)\end{array}$ & $\begin{array}{c}\geq \text { second-line } \\
(\mathbf{n}=568)\end{array}$ & $\begin{array}{c}\text { First-line } \\
(\mathbf{n}=140)\end{array}$ & $\begin{array}{c}\geq \text { second-line } \\
(\mathbf{n}=\mathbf{2 0 3})\end{array}$ \\
\hline Age & $57.1(13.4)$ & $57.1(12.2)$ & $59.5(14.7)$ & $56.6(13.2)$ \\
DAS28 (CRP) & $4.7(1.2)$ & $4.7(1.2)$ & $4.8(1.1)$ & $4.8(1.2)$ \\
CDAI & $26.6(12.5)$ & $26.6(12.4)$ & $27.7(12.5)$ & $28.6(13.8)$ \\
SDAl & $28.1(13.1)$ & $28.1(12.9)$ & $29.1(12.9)$ & $30.2(14.7)$ \\
\hline
\end{tabular}

Data are mean (SD). Patients with missing data for BL RF/ACPA status are excluded.ACPA=anti-citrullinated protein antibody; $\mathrm{BL}=$ baseline. whom abatacept was $\geq$ second-line. For patients with $-/-$ RA, mean (SE) change from BL in DAS28 (CRP) was -1.03 (0.13) for those in whom abatacept was firstline and $-0.93(0.12)$ for those in whom abatacept was $\geq$ second-line. Remission rates (LOCF) were significantly $(\mathrm{p}<0.0001)$ higher in patients with $+/+\mathrm{RA}$ vs -1 RA respectively: DAS28 (CRP) $38.4 \%(n=393)$ versus $19.3 \%(n=62)$; CDAI 50.6\% $(n=513)$ versus $33.0 \%(n=107)$; and SDAI $49.5 \%(n=497)$ versus $32.5 \%(n=102)$. Conclusion: In this real-world analysis, patients with +/+ RA treated with firstline abatacept had higher retention than patients receiving abatacept as $a \geq$ second-line therapy. Remission rates on abatacept were higher in patients with $+/+$ RA versus -/- RA. These results support early treatment with abatacept and highlight the importance of further evaluating precision medicine approaches in RA.

\section{REFERENCES:}

[1] Smolen JS, et al. Ann Rheum Dis 2020;79:685-699.

[2] Alten R, et al. Ann Rheum Dis 2019;78(suppl 2):A1639.

Figure 1. Retention rates by treatment group in patients with $+/+$ RA

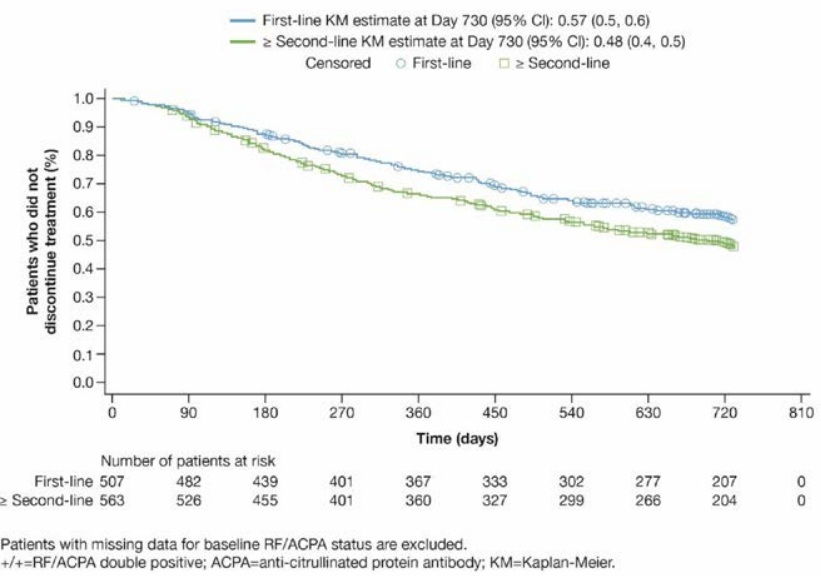

Acknowledgements: Professional medical writing and editorial assistance was provided by Lindsay Craik at Caudex and was funded by Bristol Myers Squibb. This study was funded by Bristol Myers Squibb.

Disclosure of Interests: Rieke Alten Speakers bureau: AbbVie, Bristol Myers Squibb, Gilead, Janssen, Lilly, Pfizer, Consultant of: AbbVie, Bristol Myers Squibb, Gilead, Janssen, Lilly, Pfizer, Grant/research support from: AbbVie, Bristol Myers Squibb, Gilead, Janssen, Lilly, Pfizer, Xavier Mariette Consultant of: Bristol Myers Squibb, Galapagos, Gilead, GlaxoSmithKline, Janssen, Pfizer, UCB, Rene-Marc Flipo Speakers bureau: AbbVie, Bristol Myers Squibb, Janssen, Lilly, Medac, Merck Sharp \& Dohme, Novartis, Pfizer, Roche-Chugai, Grant/research support from: Amgen, Janssen, Novartis, Pfizer, Roberto Caporali Speakers bureau: AbbVie, Amgen, Bristol Myers Squibb, Celltrion, Fresenius Kabi, Galapagos, Gilead, Lilly, Merck Sharp \& Dohme, Pfizer, Roche, Samsung Bioepis, Sanofi, UCB, Consultant of: Galapagos, Gilead, Janssen, Lilly, Merck Sharp \& Dohme, Maya H Buch Speakers bureau: AbbVie, Consultant of: AbbVie, Eli Lilly, Gilead, Merck Serono, Pfizer, Roche, Sanofi, Grant/research support from: Gilead, Pfizer, Roche, UCB, Yusuf Patel: None declared, Raimón Sanmartí Speakers bureau: AbbVie, Bristol Myers Squibb, Gebro, Janssen, Lilly, Merck Sharp \& Dohme, Pfizer, Roche, Sanofi, Consultant of: AbbVie, Bristol Myers Squibb, Gebro, Lilly, Merck Sharp \& Dohme Pfizer, Roche, Sanofi, Grant/research support from: Bristol Myers Squibb, Merck Sharp \& Dohme, Pfizer, Sara Marsal Speakers bureau: Bristol Myers Squibb, Celgene, Pfizer, Roche, Sanofi, UCB, Consultant of: AbbVie, Bristol Myers Squibb, Celgene, Galapagos, Merck Sharp \& Dohme, Pfizer, Roche, Sanofi, UCB, Grant research support from: AbbVie, Bristol Myers Squibb, Celgene, Janssen, Merck Sharp \& Dohme, Novartis, Pfizer, Roche, Sanofi, UCB, M.T. Nurmohamed Speak ers bureau: AbbVie, Bristol Myers Squibb, Eli Lilly, Roche, Sanofi, Consultant of: AbbVie, Celgene, Celltrion, Eli Lilly, Janssen, Grant/research support from: AbbVie, Bristol Myers Squibb, Celgene, Eli Lilly, Janssen, Merck Sharp \& Dohme, Mundipharma, Novartis, Pfizer, Roche, Sanofi, Hedley Griffiths Consultant of: AbbVie, Gilead, Janssen, Novartis, Peter Peichl: None declared, Bettina Bannert: None declared, Adrian Forster: None declared, Melanie Chartier Shareholder of: Bristol Myers Squibb, Employee of: Bristol Myers Squibb, Sean Connolly Shareholder of: Bristol Myers Squibb, Employee of: Bristol Myers Squibb, Yedid Elbez Consultant of: Bristol Myers Squibb, Christiane Rauch Shareholder of: Bristol Myers Squibb Employee of: Bristol Myers Squibb, Vadim Khaychuk Shareholder of: Bristol Myers Squibb, Employee of: Bristol Myers Squibb, Karissa Lozenski Shareholder of: Bristol Myers Squibb, Employee of: Bristol Myers Squibb

DOI: 10.1136/annrheumdis-2021-eular.932 